\title{
ADDITIONS TO THE LIST OF PHILIPPINE BIRDS, WITH DESCRIPTIONS OF NEW AND RARE SPECIES.
}

\author{
By Edgar Alexander Mearns, \\ Associate in Zoology, U. S. National Museum.
}

This is the seventh of a series of papers on Philippine birds, published by the writer, adding, in all, 56 species to the list of those previously known from the islands. ${ }^{a}$ It is the writer's intention soon to publish a list of Dr. Paul Bartsch's Philippine collection of birds, in which two additional forms will be described.

The following are additions to the species recorded from the Philippine Islands:

\section{STERNA LONGIPENNIS Nordmann.}

NORDMANN'S TERN.

I collected five specimens (Nos. 14065-69, author's collection) of this species, in Basilan Strait, off Zamboanga, Mindanao, April 19, 1906. Four were preserved as skins (Cat. Nos. 200770-73, U.S.N.M.) and one in alcohol.

\section{LOBIPES LOBATUS (Linnæus).}

NORTHERN PHALAROPE.

On several occasions I had seen flocks of phalaropes on the seas surrounding the Philippine Islands; and on April 19, 1906, three specimens were collected in Basilan Strait, which connects the Sulu and Celebes seas. These are Cat. Nos. 200774-6, U.S.N.M.

TANYGNATHUS MEGALORHYNCHOS (Boddaert).

GREAT-BILLED PARROT.

On January 23 and October 8, 1906, this large green parrot was found in considerable numbers on Sarangani and Balut Islands of the Sarangani group, off southern Mindanao. An adult female (Cat. No. 200811, U.S.N.M.) was collected on Balut Island, January $23,1906$.

The following are believed to be new to science:

${ }^{a}$ See Proc. Biol. Soc. Washington, XVIII, January 20, 1905, pp. 1-8; February 21, 1905, p. 73; February 21, 1905, pp. 83-90; June 29, 1905, p. 185; Philippine Journ. Sci., II, October, 1907, p. 353 ; pp. 355-360. 
PHAPITRERON SAMARENSIS, new species.

SAMAR BROWN PIGEON.

Type-Cat. No. 161096, U.S.N.M. Adult female. Collected in March, 1888, on the island of Samar, Philippine Islands, by Dr. F. S. Bourns.

Characters.-Resembling Phapitreron brevirostris, but with forehead, chin, and throat whiter than in $P$. albifrons McGregor. From $P$. brevirostris it is readily distinguishable by the white forehead, chin, and upper throat, also by the much greater amount of coppery amethystine reflections on the crown, breast, and upper back, and by the usual absence of green reflections on the side of the hind head below the suborbital white stripe; and the under parts are much paler. From $P$. albifrons it may be at once distinguished by the different color of the under parts, which lack the olivaceous-gray on the breast, and by its more ochraceous abdomen; also the coppery reflections on the breast and upper back of $P$. samarensis are entirely absent in $P$. albifrons.

Measurements of type (from well-made skin of female).-Total length, $230 \mathrm{~mm}$; wing, 124; tail, 95; culmen and cere (chord), 14; tarsus, 19; middle toe with claw, 26. "Eyes pink. Feet, base of mandible, and around eyes, dark purple. Tip of bill black. Egg taken from ovary." (F. S. Bourns.)

Measurements of adult male (Cat. No. 161095, U.S.N.M., collected in April, 1888, on the island of Samar, by Dr. F. S. Bourns).Wing, $129 \mathrm{~mm}$; tail, 95; culmen and cere (chord), 14.5; tarsus, 20 ; middle toe with claw, 27.

MUSCADIVORES PALMASENSIS, new species.

PALMAS ISLAND FRUIT-EATING PIGEON.

Type.-Cat. No. 200839, U.S.N.M. Adult male. Collected January 21, 1906, on Palmas Island, in the Celebes Sea, Philippine Islands, by Edgar A. Mearns. (Original number, 13889.)

Characters.-Closely related to Muscadivores pickeringi from Mangsee Island, north of Borneo, on the west side of the Sulu Sea; also to Muscadivores langhornei Mearns, from West Bolod Island, southeast of the Sulu Sea and near the island of Basilan. From the type of pickeringi (Cat. No. 15732 U.S.N.M.) it differs in being paler, with much less vinaceous color on the chin, throat, breast, and under tail-coverts. The wing is $10 \mathrm{~mm}$. shorter. From langhornei, which it resembles more closely in the coloration of the under parts, it can be distinguished at a glance by the dark color of the mantle, rump, and upper tail-coverts.

Adult male (type, killed January 21).-Head, neck, upper back, and under parts, lilac-gray, purest on the upper side of neck and 
upper back, washed with vinaceous on crown, ear-coverts, and breast, fading to whitish around base of bill, and shading to drab-gray on legs and crissum; scapulars, back, rump, and wing-coverts mouse gray, lustrous in a certain light; wing-quills and upper tail-coverts dark mouse gray, with subdued reflections of violet, coppery, and green; rectrices lustrous golden green above, smoke gray below; flanks, axillars, and lining of wings clear gray. An adult male topotype in fresh plumage, shot by Dr. Paul C. Freer, October 7, 1906, only differs from the type in being appreciably darker. The sexes are practically alike in size and color.

Colors of soft parts.-Two mated pairs, about to breed, had the soft parts colored exactly alike, January 21, 1906: Iris red; eyelids and feet vinaceous; claws dusky purplish gray; bare space surrounding eye, pale plumbeous; bill pale bluish gray at tip, darkerplumbeous-at base. Testicles functionally enlarged.

Measurements of two adult males (type and topotype measured fresh by the author).- Total length, 420, $430 \mathrm{~mm}$.; alar expanse, 735 , 750; wing, 240, 240; tail, 156, 160; culmen (chord), 20, 20; tarsus, 32,34 ; middle toe with claw, 46,49 .

OTUS STEEREI, new species.

TUMINDAO SCOPS OWL

Type.-Cat. No. 210752, U.S.N.M. Adult male. Collected by Edgar A. Mearns, October 13, 1906, on Tumindao Island, off Sitanki Island, Philippine Islands. (Original number, 14421.)

Characters.-Very similar to the Celebesian Otus menadensis, from which it may be distinguished by being larger, with upper parts darker, with more of the black vermiculations; black centers to the feathers of the under parts much less conspicuous; feathers of tarsus more heavily cross-barred with blackish. Of the Philippine species it is most closely related to Otus cuyensis McGregor, but is darker and much smaller, having the same white, black-tipped scapulars, but with the entire plumage darker and more heavily marked, and the wing about $15 \mathrm{~mm}$. shorter. It bears no close resemblance to any other Philippine species.

Measurements.-Wing, $157 \mathrm{~mm}$; t tail, 84; culmen from cere (chord), 15; tarsus, 33. Iris yellow; bill and feet greenish (from fresh specimen). The stomach of the type contained insects.

Named for J. B. Steere, known for his studies of Philippine birds.

PRIONITURUS MALINDANGENSIS, new species.

MOUNT MALINDANG RACQUET-TAILED PARROT.

Type.-Cat. No. 200887, U.S.N.M. Adult female. Collected at 5,000 feet altitude on Mount Lebo, a spur of Mount Malindang, Misamis Province, northwestern Mindanao, Philippine Islands, May 14, 1906, by Edgar A. Mearns. (Original number, 14131.) 
Characters.-Closely related to Prioniturus waterstradti Rothschild, from Mount Apo, southeastern Mindanao, from which it may be distinguished by its larger size, much yellower coloring of under side, greener, less brownish back and scapulars, longer tail, but much shorter naked shafts to the central pair of feathers.

Adult female (type and only specimen).-Upper parts green, with slight touches of bluish on forehead, and a light greenish brown rump, as in $P$. waterstradti; wings bright green above, with concealed inner webs blackish, and outer webs narrowly edged with yellow; edge of wing pale yellow; rectrices green above tipped with dull black, beryl green on under side, the shafts and spatules of the central pair dull black, with webs all green to the naked shafts; entire under parts golden green; axillars and lining of wings oil green; under side of primaries dull black, broadly bordered on the inner webs with beryl green. Iris dark brown; bill pale horn color, faintly plumbeous at base and tip of mandibles; feet and claws plumbeous (from fresh specimen).

Measurements of type (female).-Wing, $153 \mathrm{~mm}$.; tail, 79 (to end of lengthened central pair, 126); culmen from cere (chord), 20; tarsus, 16 ; middle toe with claw, 25 .

Measurements of adult female topotype of P. waterstradti (Cat. No. 192136, U.S.N.M.).-Wing, $145 \mathrm{~mm}$.; tail, 75 (to end of lengthened central pair, 151); culmen from cere (chord), 18; tarsus, 15; middle toe with claw, 25 (skin).

YUNGIPICUS SIASIENSIS, new species.

SIASI PIGMY WOODPECKER.

Type.-Cat. No. 210765 , U.S.N.M. Adult male from Siasi Island, Philippines, collected October 12, 1906, by Edgar A. Mearns. (Original number, 14401).

Mr. E. Hargitt, in the original description of "Iyngipicus ramsayi," a gave the type-locality as "Northeast Borneo;" but the same author ${ }^{b}$ says that the type was an adult male collected by A. Everett in the "Sulu Islands."

An adult male specimen (Cat. No. 211344, U.S.N.M.) collected by Dr. Paul Bartsch, Feburary 23, 1908, on Papahag Island, off 'TawiTawi, one of the southern islands of the Sulu group, agrees with Hargitt's Yungipicus ramsayi.

Adult male (type).- Similar to the male of $Y$. ramsayi, but with a smaller bill and without white markings on the upper surface of the primaries or secondaries except a small concealed white spot on inner webs of several secondaries, and with much less white on the inner

${ }^{a}$ Ibis, 1881, p. 598.

b British Museum Catalogue of Birds, XVIII, p. 335. 
margins of the inner webs on under side of wing; and the orangeyellow of the under parts is much more restricted, being confined to a narrow band across the chest.

Adult female (Cat. No. 210746, U.S.N.M., killed at the same time and place as the type, with which it was apparently mated).- Similar to the male, but lacking the elongated scarlet feathers on the edge of the posterior half of the crown and occiput, the entire upper surface of head and neck being dark brown. The white markings of the upper and under sides of the wings are restricted to the same extent as those of the type, and tend to form a very narrow brownish-white margin to the inner webs of the innermost secondaries, below, instead of forming squarish detached white spots as in $Y$. ramsayi; the orange-yellow pectoral band as in the male.

Measurements of Yungipicus siasiensis.-Adult male (type): Wing, $83 \mathrm{~mm}$.; tail, 47; culmen, 19.5. Adult female (Cat. No. 210764, U.S.N.M.; topotype) : Wing, $85 \mathrm{~mm}$; t tail, 49 ; culmen, 20.2.

Measurements of Yungipicus ramsayi-Adult male (Cat. No. 211344, U.S.N.M.) : Wing, 85 mm.; tail, 47; culmen, 18.

RHINOMYIAS RUFICAUDA MINDANENSIS, new subspecies.

MINDANAO RUFOUS-TAILED FLYCATCHER.

Type.-Cat. No. 190247, U.S.N.M. Adult male, collected by the writer at Pantar, Mindanao, Philippine Islands, August 24, 1903. (Original No. 12929.)

The series of this genus in the U. S. National Museum shows that there are three geographical forms of the rufous-tailed flycatcher, from the islands of Basilan, Mindanao, and Samar, respectively.

Compared with the Samar and Mindanao forms the Basilan form, Rhinomyias ruficauda ruficauda, has the under parts whiter, middle of chest grayer, sides of chest and flanks a grayer brown, with entire side of head slate-gray.

$R$. mindanensis and samarensis both have brown cheeks, and differ from each other in size, the Mindanao form being larger. The upper surfaces are of a lighter, more olivaceous, and less rufescent color.

Measurements of Rhinomyias ruficauda (Sharpe).

\begin{tabular}{|c|c|c|c|c|c|c|c|c|c|c|}
\hline 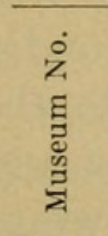 & $\begin{array}{l}\dot{0} \\
\dot{z} \\
0 \\
\dot{0} \\
0 \\
0 \\
0 \\
0\end{array}$ & 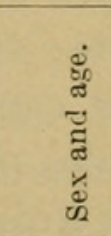 & Locality. & Date. & $\stackrel{B}{E}$ & 苟 & 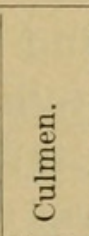 & 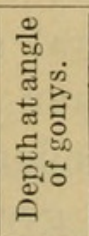 & 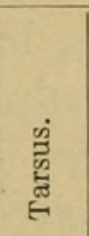 & Collector. \\
\hline 201263 & 13939 & Adult. & Isabella, Basilan . & Feb. 2,06 & ${ }_{72}^{m}$. & $m_{58}$ & $m m$. & $\begin{array}{l}m m . \\
10.5\end{array}$ & $\begin{array}{l}m m . \\
17.5\end{array}$ & Mearns. \\
\hline
\end{tabular}


Measurements of Rhinomyias ruficauda mindanensis, new subspecies.

\begin{tabular}{|c|c|c|c|c|c|c|c|c|c|c|}
\hline 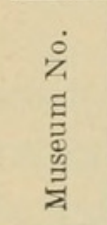 & $\begin{array}{l}\dot{0} \\
\dot{z} \\
0 \\
\dot{0} \\
\dot{0} \\
\frac{0}{\sigma} \\
\dot{0}\end{array}$ & 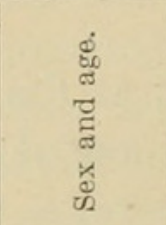 & Locality. & Date. & $\stackrel{\infty}{\Xi}$ & 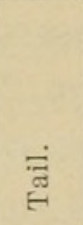 & ฏี & 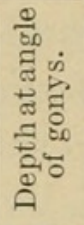 & 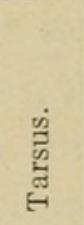 & Collector. \\
\hline $\begin{array}{l}190247 \\
210837 \\
211161 \\
200953\end{array}$ & $\begin{array}{r}12929 \\
14123 \\
17 \\
14075\end{array}$ & $\begin{array}{l}\text { Male ad... } \\
\text { Mdo........ } \\
\text { Male...... } \\
\text { Malead.. }\end{array}$ & $\begin{array}{l}\text { Pantar, Mindanao.. } \\
\text { Catagan, Mindanao. } \\
\text { Za. do............. }\end{array}$ & $\begin{array}{l}\text { Aug. } 24,03 \\
\text { May } 13,06 \\
\text { May } 21,06 \\
\text { Apr. } 25,06\end{array}$ & $\begin{array}{l}m m . \\
74 \\
77 \\
76 \\
76\end{array}$ & $\begin{array}{l}\text { mm. } \\
60.5 \\
64 \\
67 \\
65\end{array}$ & $\begin{array}{l}m m . \\
\cdots \\
\cdots\end{array}$ & $\begin{array}{l}m m . \\
11 \\
11 \\
11 \\
12\end{array}$ & $\begin{array}{l}m m . \\
17 \\
18 \\
17.3 \\
18\end{array}$ & $\begin{array}{l}\text { Mearns. } a \\
\text { Do. } \\
\text { Schroder. } \\
\text { Mearns. }\end{array}$ \\
\hline $\begin{array}{l}190246 \\
210836 \\
210838\end{array}$ & $\begin{array}{l}12893 \\
14199 \\
14213\end{array}$ & $\begin{array}{l}\text { Female ad } \\
\ldots \text { do } \ldots . . . . . \\
\ldots . \text { do } \ldots . . . .\end{array}$ & 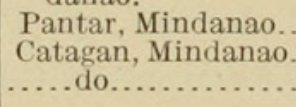 & $\begin{array}{l}\text { Aug. } 13,03 \\
\text { May 23,06 } \\
\text { May } 25,06\end{array}$ & $\begin{array}{l}73 \\
74 \\
74\end{array}$ & $\begin{array}{l}56 \\
60 \\
60\end{array}$ & & $\begin{array}{l}10 \\
10.2 \\
10.6\end{array}$ & $\begin{array}{l}16 \\
17 \\
16\end{array}$ & $\begin{array}{l}\text { Do. } \\
\text { Do. } \\
\text { Do. }\end{array}$ \\
\hline
\end{tabular}

Measurements of Rhinomyias samarensis Steere.

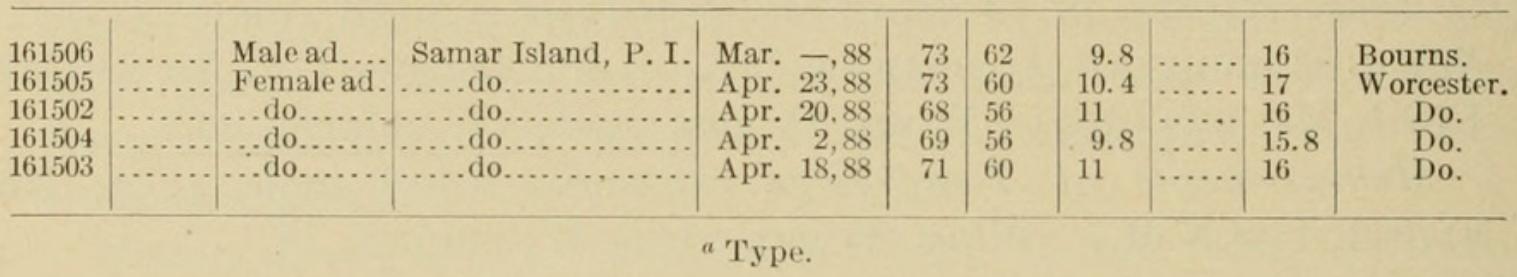

CRYPTOLOPHA MALINDANGENSIS, new species.

MOUNT MALINDANG FLYCATCHER-WARBLER.

Type.-Cat. No: 202360, U.S.N.M. Adult male. Summit of Grand Malindang Mountain (altitude slightly above 9,000 feet), Misamis Province, northwestern Mindanao, Philippine Islands, June 5, 1906. Collected by Edgar A. Mearns. (Original number, 14275.)

Characters.-Similar to Cryptolopha mindanensis Hartert, from Mount Apo, Mindanao, but smaller, less yellow above and below, and with a distinct yellowish-white post-ocular streak extending to the occiput; bill flesh color instead of yellow on base of mandible; feet grayish flesh color instead of plumbeous.

Adult male.-Upper parts olive-green, darkest on the crown; wings and tail dark brown, broadly bordered with olive-green on the outer webs, but with outer rectrix white to the base, edged with pale yellow basally and with olive-brown terminally on outer web; second rectrix dark brown at base of inner web, white on terminal two-thirds, yellow on basal half of outer web, and olive-brown on terminal half; third rectrix edged with white at tip of inner web and yellow on outer web at base; loral and post-ocular streak yellowish white; entire under parts sulphur yellow, obscured by pale olive-green centers to the feathers; under tail-coverts plain sulphur yellow; sides of chest and flanks olive-green, streaked with yellow; axillars and lining of wings pale sulphur yellow; cheeks pale sulphur yellow, mottled with very pale olive-green; iris hazel; bill brownish black, flesh color at base of mandible; feet grayish flesh color, claws brown (from fresh specimen). 
Comparative measurements of Cryptolopha mindanensis and $C$. malindangensis.-Adult males (from skins): Wing, 58, $56 \mathrm{~mm}$.; tail, 48, 46; bill from nostril, 7, 7; tarsus, 21, 21.

Material.-Five specimens of Cryptolopha mindanensis and 11 of C. malindangensis.

Range.-From 5,000 to 9,000 feet on the Malindang Mountains.

PSEUDOTHARRHALEUS MALINDANGENSIS, new species.

MOUNT MALINDANG WOOD-ACCENTOR.

Type.-Cat. No. 210853, U.S.N.M. Adult male. Summit of Mount Malindang, northwestern Mindanao, Philippine Islands, altitude slightly above 9,000 feet, June 6, 1906. Collected by Edgar A. Mearns. (Original number, 14277.)

Characters.-The largest known species of Pseudotharrhaleus; gray of cheeks and supraorbital stripe obscured by heavy markings of brown; feathers of chest heavily marked with black centers.

Adult male (type and only specimen).-General color above burnt umber, washed with Vandyke brown on rump and upper tail-coverts; tail darker; wing-quills brownish black, with outer webs broadly margined with the same color as the upper parts and extending to the outer webs of the under side of wing; head sepia above, without an appreciable supraorbital stripe; sides of head grayish brown, maculated with bister; chin and upper throat dirty whitish; much obscured by dusky macules occupying the centers of the feathers; middle of chest gray, heavily marked with blackish centers to the feathers; sides, crissum and under tail-coverts, axillars, and lining of wings like the back, this color shading to wood brown on middle of belly; iris brown; bill plumbeous-black; feet and claws brown (from fresh specimen). The following measurements were taken from the type specimen, freshly killed, by the writer: Total length, $196 \mathrm{~mm}$.; alar expanse, 212 ; wing, 66 ; tail, 90 ; culmen (chord), 16.5; bill from nostril, 10.3; from occiput to tip of bill, 42 ; tarsus, 28 ; middle toe with claw, 25.

This bird was usually found in hollows under mossy logs. Its note resembles the alarm call of the American Pipilo fuscus mesoleucus.

BRACHYPTERYX MALINDANGENSIS, new species.

MOUNT MALINDANG SHORTWING.

Type-Cat. No. 202137, U.S.N.M. Adult female. Summit of Grand Malindang Mountains, altitude 9,000 feet, Misamis Province, northwestern Mindanao, Philippine Islands, June 5, 1906. Collected by Edgar A. Mearns. (Original number 14269.)

Characters.-Most closely related to Brachypteryx brunneiceps Grant and B. mindanensis Mearns. Smaller than brunneiceps, about equaling mindanensis; coloration very dark; russet of front of head 
intensified to almost a burnt umber, and not extending backward beyond the eyes; edge and lining of wings, slate color, instead of rusty.

Adult male--(Cat. No. 202136, U.S.N.M. A topotype from the summit of Mount Malindang, altitude 9,000 feet, June 5, 1906).Uniformly slate-black, becoming practically black on the whole head, except a minute and wholly concealed supraorbital white spot. Iris dark reddish brown; bill all jet black; feet and claws plumbeousblack (from fresh specimen).

Adult female (type).-Front of head back to the eyes rusty burnt umber, with eye-ring of same color; hind half of head, neck all round, and all of body except abdomen, blackish slate; abdomen washed with brownish gray; wings and tail brownish black, washed with slate-color; edge and lining of wings slate-color, not russet. The colors of the iris, bill, and feet were noted as exactly like those of the male topotype.

Measurements.-Adult male (Cat. No. 202136, U.S.N.M.) : Total length, $160 \mathrm{~mm}$; alar expanse, 222; wing, 70 ; tail, 60; culmen (chord), 14.5 ; bill from nostril, 9 ; tarsus, 32 ; middle toe with claw, 24. Adult female (type) : Total length, $148 \mathrm{~mm}$; alar expanse, 213; wing, 66 ; tail, 53 ; culmen (chord), 13 ; bill from nostril, 8.5 ; tarsus, 34 ; middle toe with claw, 24.5 .

HYLOTERPE APOENSIS BASILANICA, new subspecies.

BASILAN ISLAND THICK-HEAD.

Type-Cat. No. 161534, U.S.N.M. Adult male. Collected on the island of Basilan, Philippine Islands, November 8, 1887, by D. C. Worcester.

Adult male.-Similar to typical Hyloterpe apoensis, but paler throughout, with crown brownish instead of grayish; underparts canary yellow instead of lemon yellow; slightly smaller. Wing, $78 \mathrm{~mm}$.; tail, 67 ; culmen, 14; bill from nostril, 9.2; tarsus, 17.5; "Iris brown. Bill black."

Adult female.-(Cat. No. 201258 U.S.N.M. Collected on the island of Basilan, Philippine Islands, February 19, 1906, by Edgar A. Mearns. Original number, 13962). Paler and dingier than the male; under parts pale canary yellow from throat backward. Wing, $71 \mathrm{~mm}$. ; tail, 61 ; tarsus, 17.5 .

Remarks.-Specimens in the U. S. National Museum, collected on the island of Siquijor, Philippine Islands, by F. S. Bourns and D. C. Worcester, are exactly like Basilan specimens taken in February, 1888 , and must be included as belonging to this subspecies. Lowland birds from Mindanao Island connect the forms apoensis and basitanica. 
ZOSTEROPS GOODFELLOWI MALINDANGENSIS, new subspecies.

MOUNT MALINDANGG SILVER-EYE.

Type-Cat. No. 202401, U.S.N.M. Adult male. Summit of Mount Lebo (Malindang group), altitude 5,750 feet, Misamis Province, northwestern Mindanao, May 21, 1906. Collected by Edgar A. Mearns (original number 14169).

Characters.-Smaller than typical Zosterops goodfellowi, with stouter bill, front half of head grayish brown instead of olive-green; nape greenish gray instead of olive-green; auricular patch more sharply defined and less greenish; malar region washed with brown instead of being dirty white; throat and upper breast more distinctly washed with brown. The iris is reddish brown in both; bill black in malindangensis, plumbeous-black in goodfellowi; feet and claws pale olive, yellowish on under side of toes in both.

Measurements of Zosterops goodfellowi goodfellowi and Zosterops goodfellowi malindangensis contrasted.-Adult males (measured in the flesh by the writer): Total length, 156-147 mm.; alar expanse, 231-218; wing, 75-70; tail, 61-57; culmen (chord) 13-15; tarsus, 21-21; middle toe with claw, 16-16.5. Adult females (measurements from dry skins): Wing, 70-63 mm.; tail, 59-54; culmen (chord), 12.5-13.5; tarsus, 21-21.

Material.-Seven specimens of typical goodfeilowi from Mount Apo and eleven of the present form from the Malindang group of mountains.

Range.-From 5,000 feet on Lebo and Bliss peaks up to the summit of Grand Malindang (9,000 feet).

\section{CYRTOSTOMUS JUGULARIS MINDANENSIS, new subspecies.}

MINDANAO YELLOW-BREASTED SUNBIRD.

Type.-Cat. No. 192061, U.S.N.M. Adult male. Collected January 24, 1904, at Zamboanga, western Mindanao, Philippine Islands, by Edgar A. Mearns. (Original number, 13177.)

Characters.-Most closely resembling Cyrtostomus jugularis jugularis of Luzon, but slightly larger, with the upper parts olive-green instead of brownish olive-gray; under parts nearly uniform lemon yellow instead of canary yellow.

Comparative measurements.-Males of Cyrtostomus jugularis mindanensis average: Wing, $54 \mathrm{~mm}$.; tail, 44 ; culmen (chord), 18; tarsus, 15. Males of $C \cdot j . j u g u l a r i s$ average: Wing, $50 \mathrm{~mm}$.; tail, 40 ; culmen, 18 ; tarsus, 15 . Females of $C . j$. mindanensis average: Wing, $52 \mathrm{~mm}$.; tail, 38 ; culmen, 18 ; tarsus, 14 . Females of $C . j$. jugularis average: Wing, $48 \mathrm{~mm}$; tail, 38; culmen, 17; tarsus, 14.

Material.-Twenty-six skins, from Mindanao and the offlying islands of Talicud and Buluan, the latter showing a tendency to 
intergrade with $C . j$. woodi. One skin from Cebu Island appears to be this form.

Remarles.-Skins from northern Mindanao, adjoining the range of C. jugularis dinagatensis (Bucas, Dinagat, Leyte, Bohol, and Panay islands) show no tendency to intergrade with dinagatensis, but, on the contrary, have the under parts paler yellow than any others from Mindanao. The range of dinagatensis separates the ranges of jugularis and mindanensis.

CYRTOSTOMUS JUGULARIS WOODI, new subspecies.

WOOD YELLOW-BREASTED SUNBIRD.

Type-Cat. No. 200602, U.S.N.M. Adult male from one of the "Three Islands," south of Sibutu Island, Philippine Islands, January 5, 1906. Shot by Leonard Wood, jr., for whom the species is named.

Characters.-Smaller than Cyrtostomus jugularis aurora, C. jugularis jugularis, or $C$. jugularis dinagatensis, old males differing from all three in the metallic reflections on the middle of the dark metallic plastron, which are bluish and violet instead of green-blue; under parts shading very gradually from rich orange, adjoining the dark metallic plastron, to clear yellow on the crissum and under tailcoverts; back a more golden olive-green than in the other Philippine forms; forehead, lores, and superciliary stripe solid metallic violetpurple.

Young male (Cat. No. 200600, U.S.N.M., from Dammi Island, in the Sulu Sea, January 4, 1906).-Middle of chin, fore neck, and throat metallic blue; sides of neck and chest orange-yellow, shading to canary yellow on crissum and under tail-coverts; upper parts golden olive-green; quills dark grayish brown, edged with olivegreen, like the back; rectrices tipped with yellowish white, broadest externally.

Measurements of type (skin).-Wing, $52 \mathrm{~mm}$.; tail, 40; culmen (chord), 16.5; bill from nostril, 14; tarsus, 14.5 ; middle toe with claw, 11.5.

- Geographical range.-Known only from three islets south of Sibutu Island, and from Dammi Island. There being no specimens from the neighboring small islands, it is not possible to define its range at the present time.

Description of the female of Cyrtostomus jugularis dinagatensis.

\section{DINAGAT ORANGE-BREASTED SUNBIRD.}

No. 202451 from Bucas Island, Philippine Islands, October 4, 1906. Shot by Capt. Halstead Dorey, U. S. Army. Similar to females of $C . j$.jugularis, but greener above and paler yellow below.

This proves to be a very distinct form, having for its range the islands of Bucas, Dinagat, Leyte, Bohol, and Panay.

Description of female of Anthreptes cagayanensis Mearns. 


\section{CAGAYAN SULU BROWN-THROATED SUNBIRD.}

Characters of adult female (Cat. No. 202463 U.S.N.M., collected Oetober 15, 1907, on Cagayan Sulu Island, in the Sulu Sea, Philippine Islands, by Edgar A. Mearns).-Differs from females of Anthreptes griseigularis in the absence of the grayish white chin and throat; from A. chlorogaster in the yellower coloration of the middle underparts and greener upper parts; and from A. malaccensis only in the greater contrast of the canary yellow of the middle underparts with the green color of the flanks, which in A. cagayanensis are pale oil-green, and in $A$. malaccensis olive-yellow. I have no female of $A$. wiglesworthi for comparison. Wing, $65 \mathrm{~mm}$.; tail, 47; culmen (chord), 15.5; bill from nostril, 12 ; tarsus, 15.8.

PYRRHULA STEEREI, new species.

STEERE BULLFINCH. ${ }^{a}$

Type-Cat. No. 210772, U.S.N.M. Adult male. Summit of Mount Bliss, Malindang group, altitude 5,750 feet, northwestern Mindanao, Philippine Islands, June 9, 1906. Collected by Edgar A. Mearns (original number 14278).

Characters.-Similar to Pyrrhula leucogenys Grant, ${ }^{b}$ from the mountains of Lepanto in northern Luzon. The Mindanao bird differs in being smaller, with a differently colored, much smaller bill, more brownish coloration, and a tendency to whitening on the middle of the abdomen, which the Luzon bird lacks.

Adult male (type, killed July 9).-Crown and front of head all round, to just behind eye, black; crown glossed with purplish blue; lores, malar region, chin, and upper throat dead black; auriculars white; scapulars and interscapular region deep broccoli brown; rump white; rectrices, upper tail-coverts, primaries, secondaries, tertials, primary coverts, and base of greater wing-coverts, glossy bluish black; lesser wing-coverts dark broccoli brown; terminal two-fifths of greater wing-coverts broccoli brown, paler terminally; outer web of innermost secondary edged externally with orange-vermilion; under parts broccoli brown, shading to whitish on middle of belly and to tawny ochraceous on crissum; axillars pure white; under wingcoverts brown at base, broadly white terminally; underside of shafts of primary quills white nearly to the tips. Fresh specimens, including the type, were noted in the field as having the iris dark brown; bill plumbeous-black, perceptibly horn color at extreme base; feet

${ }^{a}$ The section to which this bullfinch belongs has recently been made the subgenus Protopyrrhula Bianchi. Bull. Acad. Imp. Sci., St. Petersburg, 5th ser., XXV, 1906, pp. 159-198. Subgenus for P. nipalensis, erythrocephala, erythaca, and leucogenys.

${ }^{b}$ Described in the Bulletin of the British Ornithologists' Club, No. XXVIII, p. XLI, June 29, 1895. 
brownish flesh color, with under side of toes yellowish; claws brown. In the dry skins the bills are uniformly plumbeous-black.

Adult female (Cat. Nos. 202265 and 210771, U.S.N.M., topotypes taken May 27 and 30, respectively).-Exactly like the male, except that the outer web of the innermost secondary is edged externally with yellowish orange instead of orange-vermilion.

Comparison with Pyrrhula leucogenys.-The material used in making the comparison with Pyrrhula leucogenys consists of two adult females of P. leucogenys, one (Cat. No. 172435 , U.S.N.M.) a topotype collected by Mr. John Whitehead in Lepanto Province, Luzon, the other (Cat. No. 208435, U.S.N.M.) collected by the author near Paoay, Benguet Province, Luzon. The first was killed December 19, 1894, the second July 28, 1907. The December bird is in fresher plumage and somewhat darker and browner than the July specimen. The two localities were in sight of each other, perhaps 20 miles apart. In both of the Luzon birds the bills still show a large amount of yellow, as shown in Mr. Keuleman's excellent figures of the male and female (Plate 14) published in the Ibis for 1895, opposite page 455 . From a female specimen of P.leucogenys (Cat. No. 208435, U.S.N.M.) just shot I noted the following: Iris grayish brown; bill yellowish horn color, broadly black on commissural line and at tip; feet brownish flesh color; claws darker brown.

Comparative measurements of fresh specimens (by the author).Cat. No. 210771, U.S.N.M., an adult female topotype of Pyrrhula steerei, and Cat. No. 208435, an adult female of P. leucogenys, from near the type locality, presented the following measurements: Length, 152, $168 \mathrm{~mm}$.; alar expanse, 242, 259; wing, 77, 82 ; tail, 65, 71 ; culmen (chord), 10.5, 11.3; tarsus, 17.5, 18.5; middle toe with its claw, 16.5, 19 .

Remark.-It seems fitting that this species should be named in honor of Prof. J. B. Steere, who has contributed so much to our knowledge of Philippine birds.

In the following table measurements of Pyrrhula leucogenys and P. steerei, taken from dry skins, by Mr. J. H. Riley, are presented.

Measurements of Pyrrhula leucogenys.

\begin{tabular}{|c|c|c|c|c|c|c|c|c|c|c|c|}
\hline 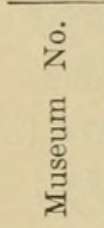 & 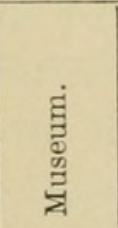 & 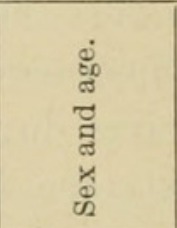 & Locality. & Date. & 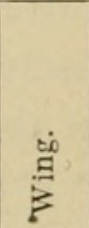 & 苟 & 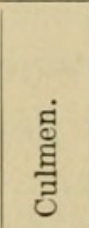 & 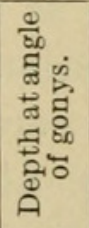 & 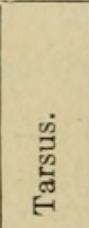 & 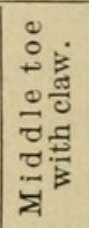 & $\begin{array}{l}-0 \\
0 \\
5 \\
0 \\
0 \\
0 \\
0 \\
0 \\
0 \\
0 \\
0\end{array}$ \\
\hline 172435 & U.S. & Female ad. & $\begin{array}{l}\text { Lepanto, North } \\
\text { Luzon. }\end{array}$ & Dec. 19 & $\begin{array}{l}m m . \\
81.5\end{array}$ & $\begin{array}{l}m m . \\
61.5\end{array}$ & $\begin{array}{l}m m . \\
11.5\end{array}$ & $m m$. & $\begin{array}{l}m m . \\
17.5\end{array}$ & $\begin{array}{l}m m . \\
19.5\end{array}$ & $\underset{10}{m m}$. \\
\hline 208435 & ...do.. & ...do... & $\begin{array}{l}\text { Near Paoay, Ben- } \\
\text { guet, Luzon. }\end{array}$ & July 28 & 79.5 & 64 & 11.5 & 11 & 18 & 19 & 10.5 \\
\hline
\end{tabular}


Measurements of Pyrrhula steerei.

\begin{tabular}{|c|c|c|c|c|c|c|c|c|c|c|c|}
\hline 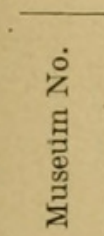 & 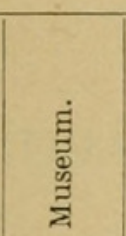 & 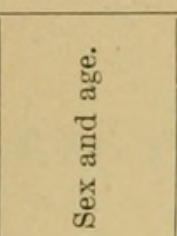 & Locality. & Date. & $\stackrel{\dot{0}}{\vec{B}}$ & 节 & 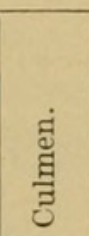 & 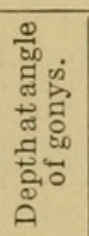 & 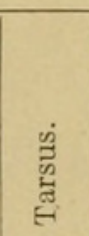 & 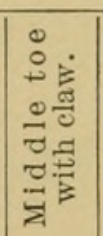 & 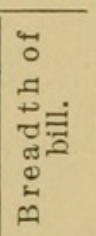 \\
\hline 202265 & U.S. . & Female ad. & $\begin{array}{l}\text { Summit of Mount } \\
\text { Bliss, Mindanao. }\end{array}$ & May 27 & $\begin{array}{r}m m \\
77\end{array}$ & $\begin{array}{l}m m . \\
61\end{array}$ & $\begin{array}{l}m m . \\
10.5\end{array}$ & $\begin{aligned} m m . & \\
9.5 & \end{aligned}$ & $\begin{array}{l}m m . \\
17\end{array}$ & $\begin{array}{l}m m . \\
17\end{array}$ & $\underset{9}{m m}$. \\
\hline $\begin{array}{l}210771 \\
210772\end{array}$ & $\begin{array}{l}\ldots \text { do } \ldots \\
\ldots \text {. do... }\end{array}$ & Male ad..... & $\begin{array}{l}\ldots . . \text { do } \\
\ldots \ldots \text { do }\end{array}$ & $\begin{array}{l}\text { May } 30 \\
\text { June } \quad 9\end{array}$ & $\begin{array}{l}78 \\
77\end{array}$ & $\begin{array}{l}60 \\
60.5\end{array}$ & $\begin{array}{l}10 \\
10.5\end{array}$ & $\begin{array}{l}9.5 \\
9.5\end{array}$ & $\begin{array}{l}17 \\
16.5\end{array}$ & $\begin{array}{l}17 \\
16.5\end{array}$ & $\begin{array}{l}9.5 \\
9.5\end{array}$ \\
\hline
\end{tabular}

DICRURUS BALICASSIUS MINDORENSIS, new subspecies.

MINDORO DRONGO SHRIKE.

Type-Cat. No. 202009, U.S.N.M. Adult male, collected at 3,000 feet altitude on Mount Halcon, Mindoro Island, November 30, 1906, by Edgar A. Mearns.

Characters.-Slightly larger than Dicrurus balicassius from Luzon Island; also differing in having the metallic reflections of the upper parts and breast greenish blue instead of bluish green.

Measurements of type (adult male).-Wing, $148 \mathrm{~mm}$; tail, 130; culmen, 27 ; tarsus, 25.

Measurements of three adult female topotypes (Cat. Nos. 202006-8, U.S.N.M.).-Wing, 143, 146, 144 mm.; tail, 128, 129, 129; culmen, $27.5,31,29$; tarsus, 26, 25, 25 .

\section{CHIBIA CAGAYANENSIS, new species.}

\section{CAGAYAN SULU DRONGO SHRIKE.}

Type.-Cat. No. 191894, U.S.N.M. Adult female from Cagayan Sulu Island, in the western part of the Sulu Sea, Philippine Islands, collected February 26, 1904, by Edgar A. Mearns. (Original number, 13285.)

Characters.-Very similar to Chibia palawanensis, differing only in its somewhat larger size, shallower forking of the tail, the narrower and very much smaller spangles on the breast, and in the absence of metallic green on the upper tail-coverts.

Measurements of skin (type and only specimen).-Length, 260 mm.; wing, 136; tail, 126; emargination of tail, 16 ; culmen (chord), 28.5 ; tarsus, 24.5 .

Measurements of two adult female topotypes of Chibia palawanensis (Cat. Nos. 161330 and 161331, U.S.N.M.).-Length, 157, $150 \mathrm{~mm}$.; wing, 133, 131; tail, 126, 130; emargination of tail, 20, 20; culmen, 28,27 ; tarsus, $23,25.5$.

Remark.-I saw a number of these birds on the island of Cagayan Sulu on my brief first visit. 


\section{$2 \mathrm{BHL}$ Biodiversity Heritage Library}

Mearns, Edgar Alexander. 1909. "Additions to the list of Philippine birds, with descriptions of new and rare species." Proceedings of the United States National Museum 36(1679), 435-447. https://doi.org/10.5479/si.00963801.36-1679.435.

View This Item Online: https://www.biodiversitylibrary.org/item/53526

DOI: https://doi.org/10.5479/si.00963801.36-1679.435

Permalink: https://www.biodiversitylibrary.org/partpdf/52554

\section{Holding Institution}

Smithsonian Libraries

\section{Sponsored by}

Smithsonian

\section{Copyright \& Reuse}

Copyright Status: Public domain. The BHL considers that this work is no longer under copyright protection.

This document was created from content at the Biodiversity Heritage Library, the world's largest open access digital library for biodiversity literature and archives. Visit BHL at https://www.biodiversitylibrary.org. 